\title{
Some biological aspects of Tetranychus urticae Koch on some soybean cultivars at three constant
} temperatures

\author{
Helmy A. Anber', Ahlam A. Younes ${ }^{2}$, Ghada M. El-Shafei ${ }^{1}$ \& Mohamed R. Ammar ${ }^{2}$ \\ ${ }^{1}$ Plant Protection Department, Faculty of Agriculture, Tanta University.E-mail, Helmyanber96@gmail.com \\ ${ }^{2}$ Cotton and Field Crops Acarology Department, Plant Protection Research Institute, ARC. E-mail, \\ EngAmmar85@yahoo.com
}

\begin{abstract}
Some biological aspects of Tetranychus urticae Koch on three soybean cultivars (i.e., Giza 21, Giza 35 and Giza 83 ) at three constant temperatures of 22,26 and $30^{\circ} \mathrm{C} ; 65 \%$ R.H. and 16:8 L: D photoperiods were studied. The results indicated that, T. urticae successfully developed on all experimental soybean cultivars at the three constant temperatures. The life cycle of $T$. urticae was the longest at $22^{\circ} \mathrm{C}$ followed by $26^{\circ} \mathrm{C}$, than $30^{\circ} \mathrm{C}$. The longevity of $T$. urticae female were 18.18 , 18.88 and 19.18 days at $22^{\circ} \mathrm{C}$, while the shortest periods were $13.65,13.85$ and 15.30 days on Giza21, Giza84 and Giza35, respectively. Significantly differences occurred between all stages at the three levels of temperatures. The highest fecundity and daily rate at $30^{\circ} \mathrm{C}$ was $95.65 \mathrm{eggs} / \mathrm{female}$ and $8.72 \mathrm{eggs} / \mathrm{O} / \mathrm{day}$, while the lowest was71.58 eggs/female and $5.33 \mathrm{eggs} / \mathrm{Q} /$ day at $22^{\circ} \mathrm{C}$. Significant differences occurred between the three varieties diets as fecundity was the highest on Giza35 and the lowest on Giza21. These results indicated that, soybean Giza35 was more susceptible to the infestation by spider mite, while Giza21 was more tolerance, whereas Giza83 was in between. The lowest threshold temperature $\left(\mathrm{t}_{0}\right)$ to different stages of the mite, $T$. urticae were recorded as: 14.26, 3.44, 6.34, 11.32, 7.93, 11.32, 9.85 and 4.66 for egg, larva, protonymph, deutonymph, immature, life cycle, generation and life span for the mite females, respectively. Whereas, $T$. urticae female required 135.4 DDUs to complete its development (egg to adult).
\end{abstract}

Keywords: biology, spider mite, fecundity, susceptibility, the lowest temperature threshold, Glycine $\max$.

\section{INTRODUCTION}

Soybean (Glycine max (L.) Merr., Fabaceae) is a major oil-seed crop grown and consumed in the world, with a worldwide production of 336.11 million metric tons in the 2019/2020 cropping season, $37 \%$ of which were grown in Brazil (USDA 2020).Soybean crops are liable to be infested by many arthropod pests of these, the two-spotted spider mite, Tetranychus urticae Koch (Acari: Tetranychidae) stands out due to its high potential to cause damage (Roggia et al. 2008).The $T$. urticae feeds on tender tissues, usually on the lower leaf surfaces, where it sucks out cell chloroplasts and other contents; the corresponding sites of the upper leaf surfaces appear as whitish or yellowish stippling. At a low density of attack, the striplings are quite distinct from the green tissues of the leaf surface, but as mite feeding continues they may join up and become brownish or yellow-brown. In addition, mite webbing develops on the lower leaf surfaces, and at high population densities may cover the leaves, flowers and fruits, or the entire plant. Severe damage induces the leaves to dry and drop, and the plant may die (Vacante 2016).

Damages produced by pests of soybean crop, ranged from 3 to $21 \%$, every year. In the lack of such control measures, damages may by increase to reach 70-100\% (Georgescu et al. 2016).

Soybean cultivars differ in terms of their susceptibility to spider mite infestation. Many researchers studied the biology of the spider mite on field crops and fruits. Ali (2002); Elhalawany and Abdel-Wahed (2013) suggested temperatures between 25 to $28^{\circ} \mathrm{C}$ to be most favorable to the T.urticae development. Dehghan et al. (2009) studied the effect of several soybean cultivars on the fitness of $T$. urticae at $25^{\circ} \mathrm{C}$. Immature developmental time was significantly longer on LWK and Gorgan 3 than on the other cultivars, whereas total fecundity per female was higher on Gorgan 3 than on the other cultivars. There were significant differences among the forms of the survival curves of mites on the cultivars. Kavousi et al. (2009) observed that on bean leaves the deutonymphal stage, the total pre-adult stage and the pre-oviposition period, were shorter (1.22, $7.6,0.29$ days) than on leaf discs $(1.73,8.2,0.89$ days), respectively. The lifetime fecundities were 22.81 and 12.05 offspring on whole leaves and leaf discs, respectively. Sedaratian et al. (2009) studied the effect of 14 soybean genotypes on life history and fecundity of T. urticae at $28^{\circ} \mathrm{C}, 65 \%$ RH. 
The highest developmental time was 8.41 and 8.78 days for male and female on $\mathrm{L}_{27}$, and the lowest value of this period was obtained on Sahar and Ks3494 for male and female (7.11 and 7.60 days, respectively). The $T$. urticae fecundity varied from 33.62 to 153.82 eggs per female, which was minimum on 032 and maximum on $\mathrm{L}_{17}$.

The tested soybean varieties greatly affected female fecundity, and the number of eggs laid by a single female of the reared mite, where the maximum numbers of laid eggs were registered on Giza22 variety (45.50 egg), while, the least ones were observed on Giza111 variety 34.50 eggs (Ezz El-Dein2018). The shortest life cycle ofT. Urticae females was recorded on Giza 35 with significant difference with Giza 22 which recorded the longest life cycle (8.9 and 10.2 days for males and females). The lowest female fecundity was 19.75 eggs/ female on Giza32, while the highest value was $31.0 \mathrm{eggs} /$ female on Giza 35 (Heikal and Abo-Taka 2019).

The objective of the present study aims to elucidates on some biological aspects of $T$. urticae on three varieties of soybean under laboratory conditions.

\section{MATERIALS AND METHODS}

\section{Biological studies of Tetranychus urticae Koch}

The stock colony of $T$. urticae was collected from soybean (Glycine $\max$ (L.), Family Fabaceae) in Gemmeiza Agriculture Research Station, Gharbia Governorate. The stock culture was maintained on soybean leaves in a rearing chamber $\left(27^{\circ} \mathrm{C}, 65 \pm 5 \% \mathrm{RH}\right.$. and $16: 8$ light (L): dark (D).

Experiments were conducted on three soybean cultivars (Giza 21, Giza 35 and Giza 83). Development and biology of $T$. urticae at three temperatures $\left(22,26\right.$ and $30 \pm 1^{\circ} \mathrm{C} ; 65 \pm 5 \%$ RH. and 16:8 L: D photoperiod). One leaflet from the first fully expanding leaf per plant of each variety was chosen. It was well washed with running water to remove any possible residuals or mites. Leaves discs of about $2.5 \mathrm{~cm}$ in diameter were made surrounded by tangle foot, and placed lower surface up on of moisten cotton wool in Petri dishes $(12 \mathrm{~cm}$ diameter). The $T$. urticae couple (male and female) was placed on each disc, for each variety. These Petri dishes were kept for 24 hours to allow mating, thereafter, males were removed, while female served as a source for known-age eggs, and larvae. About 40 hatching larvae were kept singly to a leaf of each variety and left to continue their life span. The resulted larvae were placed singly on new fresh arena leaves and examined twice daily to determine the duration of each developmental stages, longevity of males and females, life cycle, generation time, pre-oviposition, oviposition and post-oviposition period. The number of eggs laid by a single female and the daily rate of eggs was counted during the longevity of female at three constant temperatures (Abdel-Wahed and Elhalawany 2012; Elhalawany et al. 2020).

\section{Statistical analysis}

The duration of life stages of mites, reproduction and fecundity parameters were compared between the three varieties and one way analysis of variance (ANOVA) using SAS statistical software (SAS Institute, 2003). Mean separation was conducted using Tukey's HSD $(\mathrm{P}=0.05)$ in the same program. The relationship between temperature and mean developmental rate of each stage under tested temperatures was determined using liner regression, $Y=a \pm b x$, whereas: $a=$ Intercept, $b=$ slope of temperature. We can also determine the two constants. The lower developmental threshold $\mathrm{t}_{0}=-\mathrm{a} / \mathrm{b}\left({ }^{\circ} \mathrm{C}\right)$ and thermal units $\mathrm{K}=1 / \mathrm{b}$ (In DDUs), where: $\mathrm{t}_{0}$ is developmental threshold ${ }^{\circ} \mathrm{C}$; $\mathrm{b}$ is the developmental rate line slope and $\mathrm{K}$ is the developmental heat constant in degree-days.

\section{RESULTS AND DISCUSSION}

The effect of temperature on the biology of the two-spotted spider mite, Tetranychus urticae, reared at $22^{\circ}, 26^{\circ}$ and $30^{\circ} \mathrm{C}$ and $65 \pm 5 \% \mathrm{RH}$., with 16:8 L: D photoperiod on Giza21, Giza35 and Giza83 soybean varieties, are presented as follow:

Biology of T. urticae Koch female on Giza21, Giza35 and Giza83 soybean varieties at three constant temperatures

T.urticae successfully developed on all experimental soybean cultivars at the three constant temperatures $\left(22,26\right.$ and $\left.30^{\circ} \mathrm{C}\right)$. Data presented in Table (1) showed significant difference between the three soybean cultivars. The shortest period was recorded on Giza35 and the longest one was recorded on Giza21. The longest average female egg incubation periods of T. urticae were $6.30,5.58$ and 5.10 days at $22^{\circ} \mathrm{C}$ while the shortest ones were $3.18,2.95$ and 2.63 days at $30^{\circ} \mathrm{C}$ on Giza21, Giza83 and Giza35, 
respectively. The longest average female larvae periods of $T$. urticae were $2.53,2.23$ and 1.78 days at $22^{\circ} \mathrm{C}$, whereas, the shortest periods were $1.73,1.50$ and 1.38 days at $30^{\circ} \mathrm{C}$ on Giza 21 , Giza83 and Giza35, respectively.

The female immature stages and life cycle recorded the shortest ones at $30^{\circ} \mathrm{C}$ and the longest ones at $22^{\circ} \mathrm{C}$ on the three soybean cultivars. In addition, the longest female generation periods were obtained at $22^{\circ} \mathrm{C}(16.55$, 14.68 and 12.83days), while the shortest periods were $7.75,7.38$ and 6.40 days at $30^{\circ} \mathrm{C}$ for Giza21, Giza83 and Giza35, respectively(Table 1).

The longest average periods of female longevity were18.18, 18.88 and 19.18 days at $22^{\circ} \mathrm{C}$, while the shortest ones were $13.65,13.85$ and 15.30 days at $30^{\circ} \mathrm{Con}$ Giza21, Giza83 and Giza35, respectively. The longest oviposition periods averaged 13.80, 14.85 and 15.50 days, while the shortest ones were 10.15, 11.20 and 12.05 days at $30^{\circ} \mathrm{C}$ at the same varieties, respectively. Significant differences were recorded between the soybean cultivars on the total mean fecundities, the highest fecundities recorded on Giza35 and the lowest values were recorded on Giza21. The lowest mean fecundities were $66.7,78.35$ and 87.70 eggs/ female with the daily rates $(4.91,5.34$ and 5.74$)$ at $22^{\circ} \mathrm{C}$, whereas, the highest fecundities were 85.60, 95.40 and 105.9 eggs/ female at $30^{\circ}$ Con Giza 21, Giza 83 and Giza 35 , respectively (Table 1 ).

In conclusion, the above mentioned results, clearly demonstrated that, the shortest developmental times and generation periods and the highest fecundities were recorded on Giza35, whereas the longest life cycles and generation periods and the lowest fecundities were recorded on Giza21. Moreover, the optimum temperature for mite development was $30^{\circ} \mathrm{C}$ being faster than $22^{\circ}$ and $26^{\circ} \mathrm{C}$. Significantly differences occurred between all stages at the three levels of temperatures.

Similar results were obtained by Hanna et al. (1981) who reported that generation time of $T$. urticae lasted for 11.38 and 11.43 days at $27^{\circ} \mathrm{C}$, when mite fed on the two soybean varieties Hampton and Gacson, respectively. Awad et al. (2018) showed that, life cycle of $T$. urticae was completed in 11.92 and 12.98 days when fed on persimmon and pecan leaves, at $27^{\circ} \mathrm{Cand} 70 \pm 4 \%$ RH.Similar results were also, obtained by Elhalawany and Abdel-Wahed
(2013); Ezz El-Dein (2018) in agreement with the present study.

\section{Biology of T. urticae Koch males on Giza21, Giza35 and Giza83 soybean varieties at the three constant temperatures}

The obtained results presented in (Table 2) demonstrated that, the egg incubation periods of $T$. urticae males on the investigated soybean plant leaves were nearly similar to those of females at the same temperature under laboratory condition. The shortest period averaged 4.80, 4.45 and 2.65 days, while the longest periods were $6.30,5.0$ and 3.15 days at $22^{\circ} \mathrm{C}$ on Giza21, Giza83 and Giza35, respectively.

The average male durations of larval, protonymphal and deutonymphal stages of $T$. urticae fed on leaf discs of the investigated soybean cultivars at the three temperatures are completed when mite reared on three soybean leaf discs (Table2). The shortest period was1.30, 1.10 and 1.05 days on Giza35 at $30^{\circ} \mathrm{C}$. The male longevity and life span periods of $T$. urticae were influenced by host plants, the shortest period was obtained on Giza 35 while, and the longest period was recorded on Giza 21.

\section{Effect of soybean varieties on biological aspects of $T$. urticae Koch}

The durations of all developmental stages were longer on Giza 21 followed by Giza 83 and Giza 35 (Table 3). Significant differences were found between developmental periods of mites exposed to different sources of food. The finding in Tables (3 and4) showed that the average egg incubation period of T. urticae was affected by soybean variety; it was the shortest on Giza 35 (3.97 and 2.90 days) and the longest on Giza 21 (4.83 and 5.52 days) for female and male, respectively.

Soybean cultivars affected the durations of the longest periods of larval, protonymphal, deutonymphal and the total immature stages. Significant differences were recorded between the three soybean cultivars for immature stages and the life cycles; the longest periods were 5.98 \& 10.80 and $6.23 \& 11.77$ days on Giza 21 variety, whereas, the shortest values were observed on Giza 35 variety (4.64 \& 8.60 and $3.88 \& 6.78$ days) on female and male, respectively (Tables 3 and4). 
Table 1. Mean developmental time (in days) of Tetranychus urticae females reared on three soybean cultivars

\begin{tabular}{lccccccccc}
\hline \multirow{2}{*}{ Variable } & \multicolumn{3}{c}{ Giza 21} & \multicolumn{3}{c}{ Giza 83} & \multicolumn{3}{c}{ Giza 35 } \\
\cline { 2 - 10 } & $22^{\circ} \mathrm{C}$ & $26^{\circ} \mathrm{C}$ & $30^{\circ} \mathrm{C}$ & $22^{\circ} \mathrm{C}$ & $26^{\circ} \mathrm{C}$ & $30{ }^{\circ} \mathrm{C}$ & $22^{\circ} \mathrm{C}$ & $26^{\circ} \mathrm{C}$ & $30^{\circ} \mathrm{C}$ \\
\hline Incubation period & 6.30 & 5.00 & 3.18 & 5.68 & 4.70 & 2.95 & 5.10 & 4.18 & 2.63 \\
\hline Larva & 2.53 & 2.45 & 1.73 & 2.23 & 1.73 & 1.50 & 1.80 & 1.50 & 1.38 \\
\hline Protonymph & 2.23 & 1.50 & 1.45 & 2.03 & 1.45 & 1.30 & 1.78 & 1.30 & 1.18 \\
\hline Deutonymph & 3.08 & 1.58 & 1.40 & 2.53 & 1.40 & 1.63 & 2.13 & 1.63 & 1.23 \\
\hline Immature stages & 7.83 & 5.53 & 4.58 & 6.78 & 4.58 & 4.43 & 5.70 & 4.43 & 3.78 \\
\hline Life cycle & 14.13 & 10.53 & 7.75 & 12.45 & 9.28 & 7.38 & 10.80 & 8.60 & 6.40 \\
\hline Generation period & 16.55 & 12.15 & 9.45 & 14.68 & 11.25 & 8.73 & 12.83 & 10.10 & 8.43 \\
\hline Pre-oviposition period & 2.43 & 1.63 & 1.70 & 2.23 & 1.98 & 1.35 & 2.03 & 1.50 & 2.03 \\
\hline Oviposition period & 13.80 & 12.05 & 10.15 & 14.85 & 12.90 & 11.20 & 15.50 & 14.10 & 12.05 \\
\hline Post-oviposition period & 1.95 & 2.15 & 1.80 & 1.80 & 1.90 & 1.30 & 1.65 & 2.20 & 1.23 \\
\hline Longevity & 18.18 & 15.83 & 13.65 & 18.88 & 16.78 & 13.85 & 19.18 & 17.80 & 15.30 \\
\hline Mean fecundity (eggs/ + ) & 66.70 & 76.90 & 85.60 & 78.35 & 85.80 & 95.40 & 87.70 & 94.60 & 105.9 \\
\hline Daily rate (eggs/ + / day) & 4.91 & 6.42 & 8.62 & 5.34 & 6.73 & 8.59 & 5.74 & 6.81 & 8.94 \\
\hline Life span & 32.30 & 26.35 & 21.40 & 31.33 & 26.05 & 21.23 & 29.98 & 26.40 & 21.70 \\
\hline
\end{tabular}

Table 2. Mean developmental time in days of Tetranychus urticae males reared on three soybean cultivars

\begin{tabular}{lccccccccc}
\hline \multirow{2}{*}{ Variable } & \multicolumn{3}{c}{ Giza 21} & \multicolumn{3}{c}{ Giza 83 } & \multicolumn{3}{c}{ Giza 35 } \\
\cline { 2 - 10 } & $22^{\circ} \mathrm{C}$ & $26^{\circ} \mathrm{C}$ & $30^{\circ} \mathrm{C}$ & $22^{\circ} \mathrm{C}$ & $26^{\circ} \mathrm{C}$ & $30{ }^{\circ} \mathrm{C}$ & $22^{\circ} \mathrm{C}$ & $26^{\circ} \mathrm{C}$ & $30{ }^{\circ} \mathrm{C}$ \\
\hline Incubation period & 6.30 & 5.45 & 4.80 & 5.00 & 4.60 & 4.45 & 3.15 & 2.90 & 2.65 \\
\hline Larva & 2.10 & 2.10 & 1.90 & 2.65 & 1.85 & 1.30 & 1.85 & 1.30 & 1.30 \\
\hline Protonymph & 2.40 & 2.00 & 1.50 & 1.30 & 1.30 & 1.15 & 1.30 & 1.15 & 1.10 \\
\hline Deutonymph & 2.60 & 2.15 & 1.95 & 1.35 & 1.15 & 1.45 & 1.15 & 1.45 & 1.05 \\
\hline Immature stages & 7.10 & 6.25 & 5.35 & 5.30 & 4.30 & 3.90 & 4.30 & 3.90 & 3.45 \\
\hline Life cycle & 13.40 & 11.70 & 10.20 & 10.30 & 8.90 & 8.35 & 7.45 & 6.80 & 6.10 \\
\hline Longevity & 13.80 & 14.70 & 14.50 & 12.50 & 12.30 & 14.80 & 10.60 & 11.40 & 10.50 \\
\hline Life span & 27.20 & 26.40 & 24.70 & 22.80 & 21.20 & 29.40 & 18.10 & 18.20 & 16.60 \\
\hline
\end{tabular}

The shortest generation times, preoviposition and post-oviposition periods were recorded on Giza35, while the longest of these periods were found on Giza21. Significant differences were also found between adult female longevities and oviposition periods. The Giza35 was more favored to the mite followed by Giza83 and Giza21. In addition, significant differences occurred between the three varieties for female fecundity, the highest one was obtained on Giza35 and the lowest on Giza21. The total mean fecundity was affected by the soybean varieties the highest ones on Giza35 and the lowest ones recorded on Giza21, with an average of 76.40 , 86.52 and 96.08 eggs/ female on Giza21, Giza83 and Giza35 varieties, respectively (Table 3 ).

Significant difference was recorded between the soybean varieties and the numbers of female daily rate depositing eggs. The highest number was recorded on Giza $35 \quad$ (7.16 eggs/female/day), followed by 6.89 eggs/female/ day on Giza 83 and the lowest was $(6.65 \mathrm{eggs} /$ female/day) on Giza 21. Moreover, insignificant and differences were recorded for female life span on the three soybean varieties. Male followed similar trend, but having short periods. Similar results were obtained by Dehghan et al. (2009); Kavousi et al. (2009) and Awad et al. (2018). Afifi et al. (2013) studied the biology of $T$. urticae on Eggplant and showed that, the shortest mean generation was 12.08 days on Black baity cultivar, and the longest was 13.2 days on Baity cultivar.

\section{Effect of temperature on the biology of $T$. urticae}

The relationship between temperature and rate of development in insects and mites is usually 
calculated as linear, but it is actually curvilinear (Sharpe and De Michele 1977).

Data in Table (5) showed that the lower threshold temperature $\left(\mathrm{t}_{0}\right)$ to different stages of the mite, $T$. urticae recorded $14.26,3.44,6.34$, $11.32,7.93,11.32,9.85$ and 4.66 for egg, larva, protonymph, deutonymph, total immature, life cycle, generation and life span for female, respectively.

The accumulated day degrees $(\mathrm{K})$ were 47.96, 41.36, 30.0, 25.27, 92.12, 135.4, 179.17 and 548.45 DDUs for egg, larva, protonymph, deutonymph, total immature, life cycle, generation and life span for female, respectively. $\mathrm{R}^{2}$ values of $T$. urticae ranged between 0.87 and1.0 of egg, larval, protonymphal, deutonymphal, and immature stages for female (Table 5).
The simple linear regression between temperature (X) and developmental rate (Y) of $T$. urticae, the regression equation of egg, larva, protonymph, deutonymph, immature, life cycle, generation and lifespan for female were $\mathrm{Y}=$ $0.021 \mathrm{X}-0.297, \mathrm{Y}=0.024-0.083, \mathrm{Y}=0.033 \mathrm{X}-$ $0.211, \mathrm{Y}=0.04 \mathrm{X}-0.448, \mathrm{Y}=0.011 \mathrm{X}-0.086, \mathrm{Y}$ $=0.007 \mathrm{X}-0.084, \mathrm{Y}=0.006 \mathrm{X}-0.055$ and $\mathrm{Y}=$ $0.002 \mathrm{X}-0.008$,respectively (Table 5 ).

Similar results were in agreement with those obtained by Osman et al. (2012); Elhalawany and Abdel-Wahed (2013).

Generally, from the previous results, it can be concluded that, the two-spotted spider mite, $T$. urticae is considered a serious pest on some soybean crops. In the future, it should be tested physical and chemical properties related to population development of $T$. urticae, especially leaf structure should be clarified.

Table 3. Effect of soybean varieties on biological aspects of Tetranychus urticae female at different constant temperatures

\begin{tabular}{lcccccc}
\hline \multirow{2}{*}{ Stage } & \multicolumn{3}{c}{ Soybean variety } & \multirow{2}{*}{ F-value } & \multirow{2}{*}{ P-Value } & \multirow{2}{*}{ HSD } \\
\cline { 2 - 4 } & Giza 21 & Giza 83 & Giza 35 & & & 0.0002 \\
\hline Egg & $4.83^{\mathrm{a}}$ & $4.44^{\mathrm{ab}}$ & $3.97^{\mathrm{b}}$ & 114.43 & 0.48 \\
\hline Larval & $2.24^{\mathrm{a}}$ & $1.82^{\mathrm{ab}}$ & $1.56^{\mathrm{b}}$ & 10.7 & 0.0207 & 0.51 \\
\hline Protonymph & $1.73^{\mathrm{a}}$ & $1.59^{\mathrm{ab}}$ & $1.42^{\mathrm{b}}$ & 55.57 & 0.0009 & 0.19 \\
\hline Deutonymph & $2.02^{\mathrm{a}}$ & $1.85^{\mathrm{a}}$ & $1.66^{\mathrm{a}}$ & 7.06 & 0.0424 & 0.88 \\
\hline Immature stages & $5.98^{\mathrm{a}}$ & $5.26^{\mathrm{ab}}$ & $4.64^{\mathrm{b}}$ & 20.65 & 0.0062 & 1.15 \\
\hline Life cycle & $10.80^{\mathrm{a}}$ & $9.70^{\mathrm{ab}}$ & $8.60^{\mathrm{b}}$ & 42.86 & 0.0015 & 1.56 \\
\hline Generation & $12.72^{\mathrm{a}}$ & $11.55^{\mathrm{ab}}$ & $10.45^{\mathrm{b}}$ & 31.24 & 0.0028 & 2.0 \\
\hline Pre-oviposition & $1.92^{\mathrm{a}}$ & $1.85^{\mathrm{a}}$ & $1.85^{\mathrm{a}}$ & 1.35 & 0.3893 & 0.94 \\
\hline Oviposition & $12.00^{\mathrm{c}}$ & $12.98^{\mathrm{b}}$ & $13.88^{\mathrm{a}}$ & 303.3 & 0.0001 & 0.41 \\
\hline Post-oviposition & $1.97^{\mathrm{a}}$ & $1.67^{\mathrm{a}}$ & $1.69^{\mathrm{a}}$ & 6.28 & 0.0514 & 0.51 \\
\hline Longevity & $15.89^{\mathrm{b}}$ & $16.50^{\mathrm{ab}}$ & $17.43^{\mathrm{a}}$ & 69.84 & 0.0006 & 1.01 \\
\hline Fecundity & $76.40^{\mathrm{c}}$ & $86.52^{\mathrm{b}}$ & $96.08^{\mathrm{a}}$ & 276.3 & 0.0001 & 2.86 \\
\hline Daily rate & $6.65^{\mathrm{c}}$ & $6.89^{\mathrm{ab}}$ & $7.16^{\mathrm{a}}$ & 164.5 & 0.0001 & 0.47 \\
\hline Life span & $26.68^{\mathrm{a}}$ & $26.20^{\mathrm{a}}$ & $26.03^{\mathrm{a}}$ & 65.05 & 0.0007 & 2.16 \\
\hline
\end{tabular}

Means followed by same letters do not differ significantly by Tukey's HSD $(\mathrm{P}<0.05)$. 
Table 4. Effect of soybean varieties on biological aspects of Tetranychus urticae male at different constant temperatures

\begin{tabular}{|c|c|c|c|c|c|c|}
\hline \multirow{2}{*}{ Stage } & \multicolumn{3}{|c|}{ Soybean variety } & \multirow{2}{*}{ F-value } & \multirow{2}{*}{ P-Value } & \multirow{2}{*}{ HSD } \\
\hline & Giza 21 & Giza 83 & Giza 35 & & & \\
\hline Egg & $5.52^{\mathrm{a}}$ & $4.68^{b}$ & $2.90^{c}$ & 36.55 & 0.0021 & 0.82 \\
\hline Larval & $2.03^{\mathrm{a}}$ & $1.93^{\mathrm{a}}$ & $1.48^{\mathrm{a}}$ & 3.22 & 0.1421 & 0.91 \\
\hline Protonymph & $1.97^{\mathrm{a}}$ & $1.25^{\mathrm{b}}$ & $1.18^{\mathrm{b}}$ & 7.67 & 0.0368 & 0.62 \\
\hline Deutonymph & $2.23^{\mathrm{a}}$ & $1.32^{\mathrm{b}}$ & $1.22^{\mathrm{b}}$ & 6.87 & 0.0443 & 0.77 \\
\hline Immature stages & $6.23^{\mathrm{a}}$ & $4.50^{b}$ & $3.88^{\mathrm{b}}$ & 45.87 & 0.0013 & 0.73 \\
\hline Life cycle & $11.77^{\mathrm{a}}$ & $9.18^{\mathrm{b}}$ & $6.78^{\mathrm{c}}$ & 46.08 & 0.0013 & 1.42 \\
\hline Longevity & $14.33^{\mathrm{a}}$ & $13.20^{\mathrm{ab}}$ & $10.83^{b}$ & 6.06 & 0.546 & 2.67 \\
\hline Life span & $26.10^{\mathrm{a}}$ & $24.47^{\mathrm{a}}$ & $17.63^{\mathrm{a}}$ & 3.24 & 0.1409 & 9.04 \\
\hline
\end{tabular}

Means followed by same letters do not differ significantly by Tukey's HSD $(\mathrm{P}<0.05)$.

Table 5. Effect of different temperatures on biological aspects of Tetranychus urticae female on soybean varieties

\begin{tabular}{lccccc}
\hline Stage & $\mathrm{a}$ & $\mathrm{b}$ & $\mathrm{t}_{0}$ & $\mathrm{~K}$ & $\mathrm{R}^{2}$ \\
\hline Egg & -0.297 & 0.021 & 14.26 & 47.96 & 0.92 \\
\hline Larval & -0.083 & 0.024 & 3.44 & 41.36 & 0.98 \\
\hline Protonymph & -0.211 & 0.033 & 6.34 & 30 & 0.9 \\
\hline Deutonymph & -0.448 & 0.04 & 11.32 & 25.27 & 0.87 \\
\hline Immature stages & -0.086 & 0.011 & 7.93 & 92.12 & 0.96 \\
\hline Life cycle & -0.084 & 0.007 & 11.32 & 135.4 & 0.99 \\
\hline Generation & -0.055 & 0.006 & 9.85 & 179.17 & 1 \\
\hline Life span & -0.008 & 0.002 & 4.66 & 548.45 & 0.99 \\
\hline
\end{tabular}

\section{ACKNOWLEDGMENT}

Deepest gratitude to Prof. M.M. Abou-Setta and Dr. A.S. Elhalawany (Plant Protection Research Institute, Agricultural Research Centre) for their help in the statistical analysis part during the current study.

\section{REFERENCES}

Abdel-Wahed N, Elhalawany ASH. 2012. Effect of temperature degree on the biology and life table parameters of Tetranychus urticae Koch on two pear varieties. Egyptian Academic Journal of Biological Sciences, 4(1), 103-109.

Afifi AM, El-Bishlawy SM, Mohmoud H. 2013. Resistant of two Eggplant cultivars against the two-spotted spider mite; Tetranychus urticae Koch infestation, with note on its biology. Acarines, 7(2),23-27.
AliAG.2002.Developmentofthetwo-spotted spider mite, Tetranychus urticae Koch. (Acari: Tetranychidae) under certain constant temperature. Assiut Journal of Agricultural Science, 33(5), 29-37.

Awad SA, Mostafa EM, Salem AA, Mahrous ME. 2018. Development and reproduction of the two-spotted red spider mite, Tetranychus urticae Koch as influenced by feeding on leaves of three solanaceous vegetable crops under laboratory condition. Journal of Entomology, 15, 69-74.

Dehghan MS, Allahyari H, Saboori A, Nowzari J, Naveh VH. 2009. Fitness of Tetranychus urticae Koch (Acari: Tetranychidae) on different soybean cultivars: biology and fertility life-tables. International Journal of Acarology, 35(4), 341-347.

Elhalawany AS, Abdel-Wahed NM.2013. Effect of temperature and host plant on 
developmental times and life table parameters of Tetranychus urticae Koch on Persimmon trees. (Acari: Tetranychidae). Egyptian Journal of Agriculture Research, 91(2), 595-607.

Elhalawany AS, Ahmed NF, Amer AI.2020. Biological aspects of date palm dust mite Oligonychus afrasiaticus (McGregor) (Acari: Tetranychidae) on fronds of three date palm cultivars. Egyptian Academic Journal of Biological Sciences, 13(1), 8998.

Ezz El-Dein SA. 2018. Effect of some soybean varieties on biological aspects and fecundity of the two spotted spider mite, Tetranychus urticae Koch (Acari: Tetranychidae). Egyptian Academic Journal of Biological Sciences, 11(2), 8994.

Georgescu E, Cana L, Gargarita R, Rasnoveanu L. 2016.Researches concerning two spotted spider mite (Tetranychus urticae) control, at soybean crop, in south-east of the Romania. Analele Institutului National de Cercetare-Dezvoltare Agricola Fundulea, 84,209-229.

Hanna MA, Zaher MA, Sawires ZR.1981. Influence of host resistance on the biology of Tetranychus urticae Koch in soybean (Acarina: Tetranychidae). Zagazig Journal of Agriculture Research, 379,1-5.

Heikal HM, Abo-Taka SM. 2019. Susceptibility of soybean varieties to mites associated with some biological aspects. African Entomology, 27(1), 114-120.
Kavousi A, Chi H, Talebi K, Bandani A, Ashouri A, Naveh VH. 2009. Demographic traits of Tetranychus urticae(Acari: Tetranychidae) on leaf discs and whole leaves. Journal of Economic Entomology, 102, 595-601.

Osman MA, Tawfik AA, Abou-Elella GM. 2012.The impact of temperature on development and demographic parameters of Tetranychus urticae Koch. Acarines, 6, 25-30.

Roggia S, Guedes JVC, Kuss RCR, Arnemann JA, Návia D. 2008. Spider mites associated to soybean in Rio Grande do Sul, Brazil. Pesquisa Agropecuária Brasileira, 43, 295-301.

SAS Institute. 2003. SAS Statistics and Graphics Guide, Release 9.1. SAS Institute, Cary, North Carolina, 27513, USA.

Sedaratian A, Fathipour Y, Moharramipour S. 2009. Evaluation of resistance in 14 soybean genotypes to Tetranychus urticae (Acari: Tetranychidae). Journal of Pest Science, 82(2),163-170.

Sharpe, J.H. and De Michele, D.W. 1977. Reaction kinetics of poikilotherm development. Journal of Theoretical Biology, 64, 649-670.

Vacante, V. 2016.Mites of Economic Plants: Identification, Bio-Ecology and Control. British Library, London, UK, 972pp.

USDA.2020. United States Department of Agriculture. World Agricultural Production. Available from: https://apps.fas.usda.gov/psdonline/circular s/production.pdf. 